MATEC Web of Conferences 34, 06004 (2015)

DOI: $10.1051 /$ matecconf/ 20153406004

(c) Owned by the authors, published by EDP Sciences, 2015

\title{
Noctiluca sp. bioluminescence in response to the mechanical stimuli of a screw propeller
}

\author{
Jing $\operatorname{Han}^{1, a}$, Xuegang Zhang ${ }^{1}$, Guijuan $\mathrm{Li}^{1}$ \\ ${ }^{1}$ Science and Technology on Underwater Test and Control Laboratory, Dalian, China
}

\begin{abstract}
This work presents a new experiment method studying the Noctiluca sp. bioluminescence under the mechanical stimulation. It devoted to the study of the Noctiluca sp. bioluminescence triggered by the screw propeller's mechanical stimuli in the tank. The size of the tank was $2 * 1 * 1 \mathrm{~m}$. The screw propeller is fixed on a shelf and the position relative to the tank was adjustable by moving the shelf. Two methods were carried out to control the running of the screw propeller. In the first scenario, the shelf was fixed in the center of the tank and the second scenario, the shelf moved from one side to the other in the tank. At the same time, the screw propeller was running with a certain velocity. The luminescent strength of Noctiluca sp. enhanced as the increase of the screw propeller's running velocity. There were two obvious luminous areas nearby the screw propeller's blades. The luminescent area was bigger in the second scenario. Thus, when navigational ship passing the sea area which filled with Noctiluca sp. or other luminescent halobios, it will stimulate the Noctiluca sp. or other luminescent halobios bioluminescence. The ship also can be detected using the bioluminescence.
\end{abstract}

\section{Introduction}

Bioluminescence induced by multifarious stimuli has long been observed and is still under investigations because of its great complexity. In particular, the exact mechanism behind bioluminescence is not yet fully understood hitherto. Bioluminescence is the cold light. The luminescence could be irradiated by halobios with no any stimulation. The halobios also irradiated luminescence when it was exposed to some stimulation source. Compared to the last situation, the spontaneous luminescence was very faintness. There were many researchers who studied the bioluminescence under different stimulation conditions. Such as, a ship or big marine mammals could stimulate the dinoflagellate bioluminescence.[1,2] The dinoflagellate bioluminescence under the stimulation of electromagnetic field was researched by McCown et al.[3] The dinoflagellate bioluminescence was also investigated using different stimulation source, such as water flows, shear-stress, and pressure changes. $[4,5,6]$ In particular, some researchers studied the mechanism of Noctiluca scintillans bioluminescence from gene level. [7] The experiment of Noctiluca sp. bioluminescence must be carried out in night because the bioluminescence was very weak. It presented a new experiment method to study the Noctiluca sp. Bioluminescence in the paper. The screw propeller was used to disturb the water which contained Noctiluca sp. The tank size was $2 * 1 * 1 \mathrm{~m}$ and contained 1 $\mathrm{mP3P}$ of water which filled with Noctiluca sp.

\footnotetext{
a Jing Han: dlinstitute@vip.163.com
}

\section{Experimental}

\subsection{Method}

The experiment was conducted during the night. The artificial light source was turned off during the experiment. Noctiluca sp. collected from the China North Yellow Sea which was cultured in the laboratory prior to the experiment. The cultivation conditions were $12 \mathrm{~h}$ light and $12 \mathrm{~h}$ dark at $16^{\circ} \mathrm{C}$ and an initial inoculation cell density of $1 \mathrm{cell} / \mathrm{mL}$. Noctiluca sp. was fed with green microalga Tetraselmis subcordiformis (final concentration 10P4P cells $/ \mathrm{mL}$ ) for 2 days.CC When the cell density reached to $5-10$ cells $/ \mathrm{mL}$, Noctiluca sp. was diluted to 1 cell $/ \mathrm{mL}$ and culturing was continued until there was enough biomass for the experiment.

A $\operatorname{tank}(2 * 1 * 1 \mathrm{~m})$ was filled with $1 \mathrm{mP} 3 \mathrm{P}$ of sandfiltered seawater and placed in a large room so that the temperature remained constant. During the experiment, Noctiluca sp. from the laboratory cultivation and cells collected directly from the environment were mixed together at a ratio of $1: 1$. The final cell density was about $1 \mathrm{cell} / \mathrm{mL}$ which was similar to that at early stages of a red tide. The experiment tank is shown in Fig.1.

The screw propeller has seven copper Cblades $100 \mathrm{~mm}$ in diameter C(Fig.2). Two methods were used to run the screw propeller. In the first method, the shelf was fixed at the center of the tank and the screw propeller was driven from low velocity (80rpm) to high (200rpm). In the second method, the shelf moved from one side to the 
other along the long axis of the tank and the screw propeller rotated in a constant velocity(120rpm). Noctiluca sp. bioluminescence was recorded by camera.

Noctiluca sp. belongs to Pyrrhopyta and is a red tide organism. Noctiluca sp. vesiculation was visible to the naked eye. Figure 3 shows a Noctiluca sp. cell under the microscope Nikon TE-2000. Figure 4 shows Noctiluca sp. fluorescence spectrum under the instrument of fluorescence spectra and spectrograph. The result on the left upper margin of Fig.4 was obtained by spectrograph. The luminescent wavelength of Noctiluca sp.was 498nm. And the result came from instrument of fluorescence spectra was $501 \mathrm{~nm}$. The result for instrument of fluorescence spectra was more precision than spectrograph. Thus the wavelength of the Noctiluca sp. was about $500 \mathrm{~nm}$.

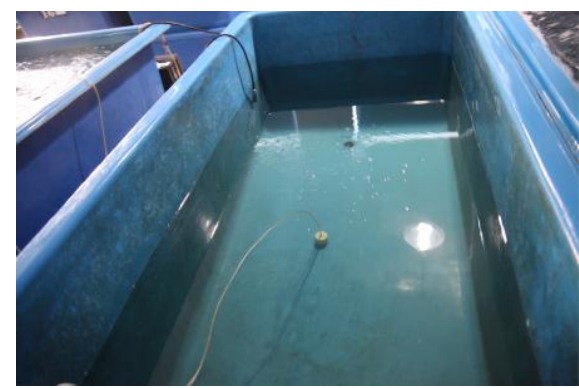

Figure.1. experiment tank

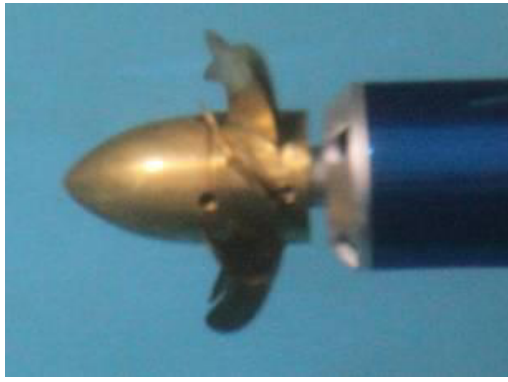

Figure.2. A screw propeller

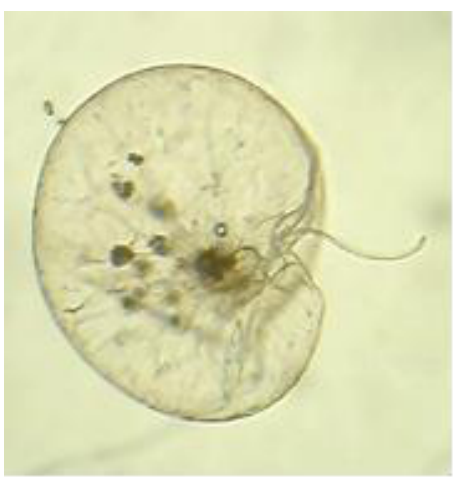

Figure.3 Noctiluca sp. cell

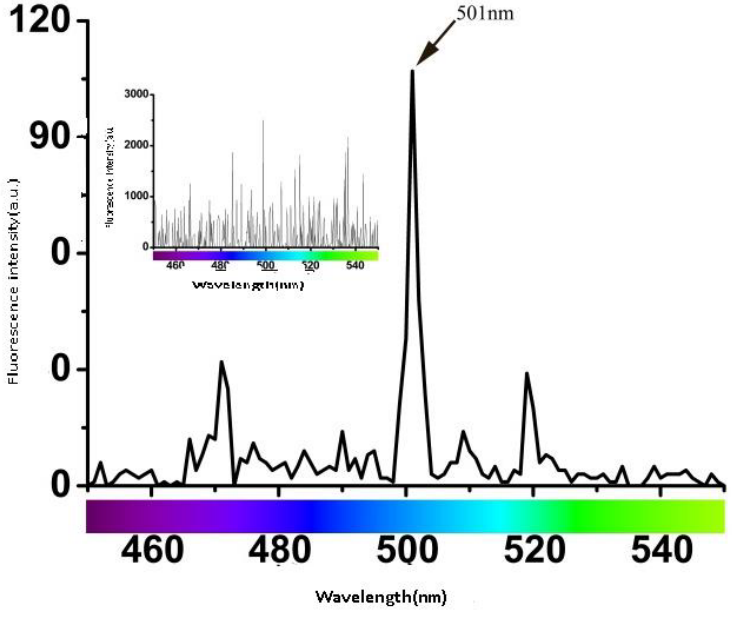

Figure.4 Fluorescence spectra

\subsection{Image analysis}

\subsubsection{Noctiluca sp. bioluminescence when the shelf was fixed and the screw propeller ran from low velocity to high.}

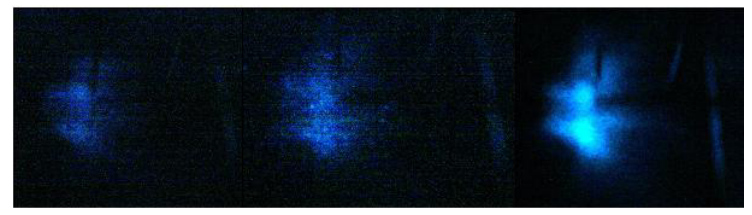

Figure.5. Noctiluca sp. bioluminescence image when rTTunning the Tscrew propeller from low velocity to high (fixed the shelf)

In the first method, the shelf was fixed at the center of the tank and the screw propeller was turned from low velocity to high. Noctiluca sp. bioluminescence images were showed in Figure.5. These images corresponded to Noctiluca sp. bioluminescence under stimuli in three different velocities (from low velocity to high) of screw propeller. These images showed that Noctiluca sp. radiated bright blue fluorescence under screw propeller running and the brightness and strength enhanced as the increase of the velocity. As the increase of the velocity, the mechanical stimuli(shear force) was also added to the Noctiluca sp. and the disturbance area also increased. So, the luminescent area was also increased. There were two obvious strongest luminescent areas in the images of Noctiluca sp. bioluminescence. These luminescent areas corresponded to the blades of the screw propeller. Thus, the mark of the screw propeller could be found on the luminescent images.

\subsubsection{Noctiluca sp. bioluminescence when moving the shelf and running the screw propeller in a certain velocity.}

In the second method, the shelf moved from one side of the tank to the other along the long axis and the screw propeller was running in a constant velocity (120rpm). The images of Noctiluca sp. bioluminescence under the 
stimuli of the moving screw propeller were showed in Figure.6. These images corresponded to Noctiluca sp. bioluminescence when the shelf in different places. Noctiluca sp. bioluminescence was the bright blue fluorescence. The luminescent area became divergence when moved the shelf. At the beginning, there were two obvious luminescent areas which corresponded to the blades of the screw propeller. As the moving of the shelf, the two luminescent areas became one bigger luminescent area at the last. The movement of the shelf disturbed more water. As the transmission of the water wave, the disturbance stimulated much more Noctiluca sp. So, the luminescent area was bigger than before. Noctiluca sp. bioluminescence was so bright that it could illuminate the shelf which fixed the screw propeller.

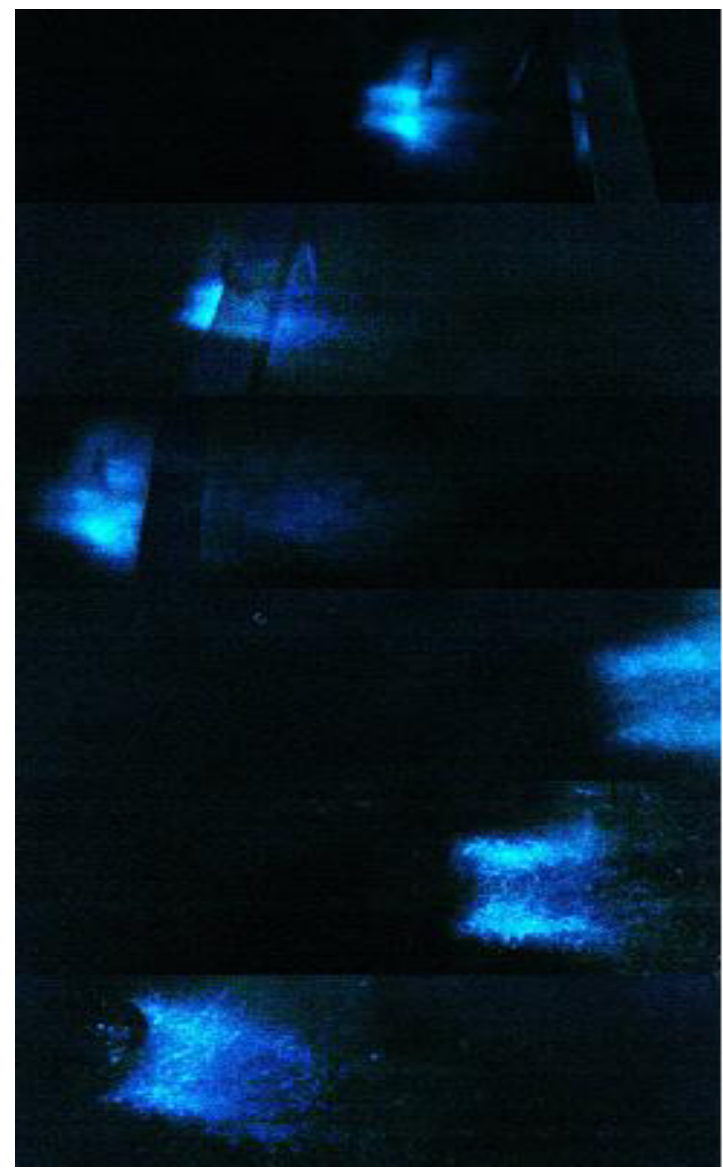

Figure.6. Noctiluca sp. bioluminescence image when running the screw propeller (the shelf movement)

\section{Result and discussion}

In this experiment, the luminescent brightness was much stronger when adding the velocity of the screw propeller at the beginning. However, the luminescent brightness did not all along increase or retain when running the screw propeller. On the contrary, the luminescent brightness of Noctiluca sp. decreased after a long time (about 10 minutes). Noctiluca sp. bioluminescence would become very weak in the last (about 20 minutes). Because of the Noctiluca sp. was damaged by the screw propeller. Thus the number of the Noctiluca sp. would decrease as the running of the screw propeller. As the death of a great deal of Noctiluca sp., the bioluminescence would very weak. The mechanical stimuli had obvious effect on Noctiluca $\mathrm{sp}$. bioluminescence.

The mark of the screw propeller could be found on the luminescent images of Noctiluca sp. There were two obvious luminescent areas which corresponded to the blades of the screw propeller. Thus, the screw propeller disturbed the Noctiluca sp bioluminescence. At the same time, the bioluminescence showed the figuration of the screw propeller. Besides, the Noctiluca sp. bioluminescence was so bright that it could illuminate the shelf which fixed the screw propeller. It could be concluded that if the bioluminescence is so brighter and stronger that it could be found from very far place. Thus, the movement of ship or dolphin in sea water stimulated the bioluminescence and the bioluminescence showed the presence of stimulation fountainhead. The figuration of stimulation fountainhead can be found from the bioluminescence images. Perhaps, the bioluminescence could be utilized in detecting the ship.

This work only studied the Noctiluca sp. bioluminescence on qualitative analysis. In the future, it will study the Noctiluca $\mathrm{sp}$. bioluminescence on quantitative analysis, such as the luminescent time, luminescent intensity.

\section{Acknowledgments}

This research work was supported by the fund under Grant No. 9140C2603110905.

\section{References}

1. Latz MI, Juhl AR, Ahmed AM, et al. The J Exp Biol, 207, pp.1941-1951 (2004).

2. Rohr J, Latz MI, Fallon S, et al. The J Exp Biol: 201, pp.1447-1460 (1998).

3. McCown RE, Gross FB, Iverson RL, et al. Proceedings of MTS/IEEE Oceans 2005 (2005).

4. Cussatlegras AS, Le Gal P. Nonlinear Process Geophys, 12, pp.337-343 (2005).

5. Maldonado EM, Latz MI. Biol Bull; 212, pp.242-249 (2007).

6. Latz MI, Case JF, Gran RL. Limnol Oceanogr; 39,6, pp.1424-1439 (1994).

7. Liu L, Hastings JW. Proc Natl Acad Sci; 104, 3: pp.696-701 (2007). 